\title{
ANTIOXIDANT AND HEPATOPROTECTIVE EFFECTS OF VIRGIN COCONUT OIL AT MAXIMUM PHYSICAL ACTIVITY
}

\author{
FAJAR APOLLO SINAGA ${ }^{1 *}$, URIP HARAHAP ${ }^{1}$, JANSEN SILALAHI ${ }^{1}$, HERBERT SIPAHUTAR ${ }^{2}$
}

${ }^{1}$ Department of Pharmaceutical Pharmacology, Faculty of Pharmacy, Universitas Sumatera Utara, Medan, Sumatera Utara, Indonesia. ${ }^{2}$ Department of Mathematics and Natural Sciences, Universitas Negeri Medan, Sumatera Utara, Indonesia. Email: uripharahap@usu.ac.id

Received: 16 October 2018, Revised and Accepted: 28 December 2018

\section{ABSTRACT}

Objective: The purpose of this study was to determine the protective effects of virgin coconut oil (VCO) treatment on hepatic oxidative stress and antioxidant defenses after maximum physical activity.

Methods: This study used 24 healthy male rats. The rats were divided into four groups randomly consisted of six rats in each group. The control group (P0) was given $2 \mathrm{~mL}$ water, the treatment groups (VCO-1, VCO-2, and VCO-4) were given VCO $1 \mathrm{ml} / 200 \mathrm{~g} \mathrm{BW,} 2 \mathrm{ml} / 200 \mathrm{~g} \mathrm{BW,} \mathrm{and} 4 \mathrm{ml} / 200 \mathrm{~g} \mathrm{BW,}$ respectively, per day using gavage spuit. The rats were trained to swim for a month, $30 \mathrm{~min} / \mathrm{day}$ in the $1^{\text {st }}$ week, 35 min/day in the $2^{\text {nd }}$ week, 40 min/ day in the $3^{\text {rd }}$ week, and $45 \mathrm{~min} /$ day in the $4^{\text {th }}$ week. After 28 days, the rats were forced to perform the maximal activity by putting the rats in water with no exit. Blood samples were collected immediately after the maximum physical activity, and then, all rats were killed and liver tissues were collected. The malondialdehyde (MDA), glutathione peroxidase (GPx), and serum glutamic-oxaloacetic transaminase and serum glutamic-pyruvate transaminase level were then measured.

Results: VCO increased swimming time to exhaustion, levels of GPx in the liver, which were accompanied by corresponding decreases in the MDA, alanine transaminase, and aspartate transaminase content.

Conclusion: The results from this study indicate that VCO is effective in the prevention of oxidative stress following maximum physical activity.

Keywords: Virgin coconut oil, Antioxidant, Hepatoprotective, Malondialdehyde, Maximum physical activity.

(C) 2019 The Authors. Published by Innovare Academic Sciences Pvt Ltd. This is an open access article under the CC BY license (http://creativecommons. org/licenses/by/4. 0/) DOI: http://dx.doi.org/10.22159/ajpcr.2019.v12i3.30299

\section{INTRODUCTION}

Exercise that is carried out routinely, regularly, and according to needs, is beneficial for health such as reducing the risk of degenerative diseases such as cardiovascular disease, some cancers, diabetes, and osteoporosis [1]. Aerobic exercise can provide many benefits to human health by increasing the fitness of the cardiorespiratory system which can improve quality of life, work efficiency, musculoskeletal function, and the strength of the cardiopulmonary system [2]. Besides, giving a positive impact on the body, physical exercise also has a negative impact. Maximum physical activity can elevate oxidative stress, leading to an imbalance between the body's oxidation system and antioxidant enzymes. Hence, accumulation of free radicals such as reactive oxygen species (ROS) can cause damage to many parts of the cells such as proteins, DNA, and cell membranes by stealing their electrons through a process called oxidation $[3,4]$. The release of ROS could result in lipid peroxidation in the mitochondrial membrane. Cellular respiration and regeneration of adenosine triphosphate (ATP) can be disrupted if there are damaged mitochondria, they are also a major cause of fatigue [5].

Maximum physical activity or high-intensity resistance can produce malondialdehyde (MDA), one of the oxidized species of membrane lipids. The level of MDA can be used as a general indicator for free radical level and indirectly pointed the oxidant capacity $[6,7,8]$. The results showed that maximum physical activity can cause an increase in MDA levels [9] and decreased levels of enzymatic antioxidants in liver tissue $[9,10]$ which resulted in liver damage which was characterized by increased levels of alanine transaminase (ALT) and aspartate transaminase (AST) [11-14].

One of the natural sources that contain antioxidants is virgin coconut oil (VCO), oil that comes from fresh old coconut (Cocos nucifera), which is processed at low temperatures [15]. Scientifically, VCO has been reported to exert various pharmacological activities such as antiarthritis and antioxidant [16], anti-thrombogenicity [17], antihyperlipidemia [18], cardioprotective [19], antimicrobial [20-22], antiosteoporosis [23], hepatoprotective [24], and antinociceptive and anti-inflammatory [25]. Interestingly, recent clinical studies demonstrated that VCO possesses at least the antihypercholesterolemic [26] and anti-Alzheimer [27]. The purpose of this study was to determine the antioxidant and hepatoprotective effects of VCO at the maximum physical activity.

\section{MATERIALS AND METHODS}

Tools

The tools used in this research were laboratory glassware, vortex (Thermo), test tube (Iwaki), Beckman Coulter (Beckman), link Dako epitope retrieval (Dako), tissue processor (Leica), spectrophotometer (Shimadzu), analytical balance (Boeco), syringe for oral feeding, flask $10 \mathrm{ml}$, stopwatch, hairdryer, animal box, syringe $1 \mathrm{ml}$, funnel, pipette, parchment, spatula, thermometer, air pump, and ruler.

\section{Materials}

Materials used in this study were $\mathrm{VICO}^{\circledR}$ is the production of PT. Patria Wiyata VICO, Indonesia, that has been registered with the Food and Drug Supervisory Agency with the registration number POM TR.052 652611.

\section{Chemicals}

Commercial assay kits for the detection of MDA and glutathione peroxidase (GPx) were purchased from PT. Biozatix Indonesia. All other chemicals used were of analytical grade and purchased from local suppliers. 


\section{Animal}

Wistar strain male rats weighing 200-220 g were obtained from the Animal House, Faculty of Pharmacy, University of Sumatera Utara. They are placed in a plastic cage in a room under standard laboratory conditions (temperatures from 20 to $30^{\circ} \mathrm{C}$, relative air humidity of $45-55 \%$, and $12 / 12 \mathrm{~h}$ of light/dark cycles). Basal diets and water ad libitum are given to meet rat nutrition. Animal trial permits carried out during this study were obtained from the Institutional Animal Ethics Committee, Department of Biology, Faculty of Mathematics and Science, University of Sumatera Utara.

\section{Experimental design}

This study used 24 healthy male rats. Rats were divided into four groups randomly consisting of six rats in each group. The control group (P0) was given $2 \mathrm{ml}$ water, the treatment groups (VCO-1, VCO-2, and VCO-4) were given VCO 1, 2, and $4 \mathrm{ml} / 200 \mathrm{~g}$ BW, respectively, per day using gavage spuit, for 28 days. The rats were trained to swim for a month, $30 \mathrm{~min} /$ day in the $1^{\text {st }}$ week, $35 \mathrm{~min} /$ day in the $2^{\text {nd }}$ week, $40 \mathrm{~min} /$ day in the $3^{\text {rd }}$ week, and $45 \mathrm{~min} /$ day in the $4^{\text {th }}$ week. After 28 days, the rats were forced to perform the maximal activity by putting the rats in water with no exit. Acrylic plastic pool $(60,50$, and $50 \mathrm{~cm}$ in length, width, and height, respectively) filled with fresh water, which was maintained at $25 \pm 0.5^{\circ} \mathrm{C}$ at a depth of $40 \mathrm{~cm}$. Exhaustion was determined by observing the loss of coordinated movements and failure to return to the surface within $10 \mathrm{~s}$. Blood samples were collected immediately after the exhaustive exercise, and then, all rats were killed and liver tissues were collected. The MDA, GPx, and AST and ALT level were then measured.

\section{Biochemical assay}

Blood sample ( $3 \mathrm{ml}$ ) was collected into a plain tube and allowed to clot for $45 \mathrm{~min}$ at room temperature. Serum was separated by centrifugation at $2500 \mathrm{rpm}$ at $30^{\circ} \mathrm{C}$ for $15 \mathrm{~min}$ and utilized for the estimation of various biochemical parameters, namely ALT and AST. The level of ALT and AST was measured by a spectrophotometer.

Phosphate buffer at pH 7.4 is used for homogenization of fresh liver tissue. The homogenate was used to estimate the levels of GPx and MDA. MDA and GPx were analyzed using an MDA and GPx assay kit according to the manufacturer's instruction.

\section{Statistical analysis}

Data of research were tested for homogeneity and normality to determine the type of statistics to be used. One-way ANOVA test was used for data analysis to determine the average difference between treatments using the SPPS 19.0 program. Then, if there is a difference, it will be followed by the Tukey test to determine the difference in value between treatment groups. Based on the significance value, $\mathrm{p}<0.05$ is considered statistically significant.

\section{RESULTS}

\section{Effect of VCO on swimming time to exhaustion of rats}

Endurance exercise is an important parameter to evaluate antifatigue treatments, and the forced swimming test has been widely used for this purpose with high reproducibility [28]. The level of exercise tolerance and fatigue can be seen with a long swim time for fatigue. As shown in Fig. 1, swimming time to exhaustion of the VCO-1, VCO-2, and VCO-4 groups was significantly longer than that of the control (C) group $(\mathrm{p}<0.05)$ with increased rates of $103.93,145.29$, and $210.59 \%$, respectively. This result indicates that VCO enhanced the exercise endurance and had antifatigue effects.

\section{Effect of VCO on GPx level}

The liver is a critical physiological metabolic organ in organisms, involved in almost all metabolism substance, and contains higher levels of antioxidant enzymes than other tissues, which, in turn, release more ROS with increased lipid peroxidation products [29]. Recent studies have demonstrated a tissue-specific expression of GPx, with their highest activities occurring in the liver $[4,12,28]$.
As shown in Fig. 2, the lever GPx levels of the VCO-1, VCO-2, and VCO-4 groups were significantly higher than that of the $\mathrm{C}$ group $(\mathrm{p}<0.05)$, with increased rates of $57.68,96.33$, and $169.62 \%$, respectively.

\section{Effect of VCO on MDA level}

Maximum physical exercise increases the production of ROS, which consequently attacks the membrane lipids and results in lipid peroxidation product formation. Significant increases in lipid peroxidation products in the liver after exhaustive exercise have been recorded in several studies [30]. MDA, one of the final products of polyunsaturated fatty acid peroxidation, has been widely investigated in exercise studies as a marker of oxidative stress [31]. As shown in Fig. 3, the MDA content of the liver of the VCO-1, VCO-2, and VCO-4 groups was significantly lower than that of the $C$ group $(\mathrm{p}<0.05)$. Moreover, the decreased rates in the liver were $58.05,70.16$, and $85.81 \%$, respectively. These results indicate that VCO effectively reduced lipid peroxidation.

\section{Effect of VCO on ALT and AST level}

The liver is the largest organ in the human body and key organ of metabolism, including glycogen storage, decomposition of red blood cells, plasma protein synthesis, and detoxification. Serum ALT and AST are the most sensitive markers of liver damage because their location is in cytoplasmic and are released into the circulation after hepatocellular damage.

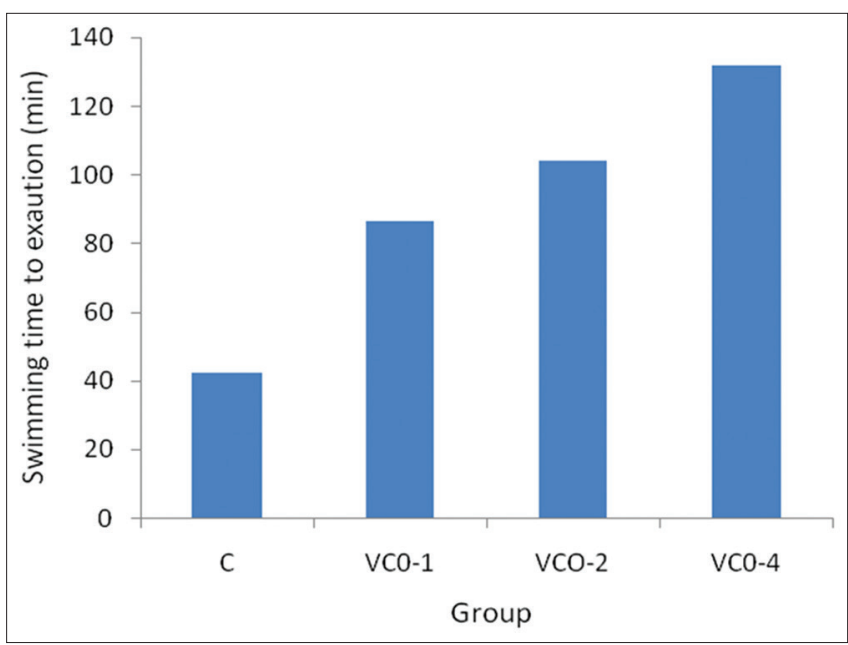

Fig. 1: Effects of virgin coconut oil on swimming time to exhaustion of rats. Data are mean \pm standard deviation; $n=6$, ${ }^{*} \mathbf{p}<0.05$ compared with control (C) group

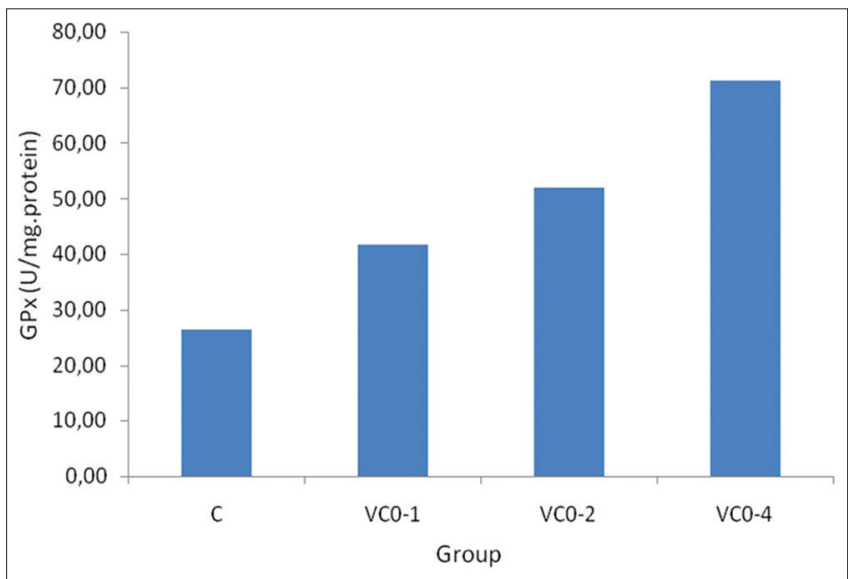

Fig. 2: Effect of virgin coconut oil on the glutathione peroxidase levels in the liver of rats. Data are the mean $\pm S D$. ${ }^{*} p<0.05$ compared with the control (C) group 
As shown in Fig. 4, the AST and ALT level of the liver of the VCO-1, VCO-2, and VCO-4 groups were significantly lower than that of the C group ( $p<0.05)$. AST level decreased in the liver was 38.27, 47.87, and $65.10 \%$, respectively, and ALT level decreased 31.51, 47.13, and $58.07 \%$, respectively.

\section{DISCUSSION}

It is known, one of the causes of the decline in performance during physical activity, especially heavy physical activity, is the increase in ROS. ROS are highly reactive molecules that cause lipid peroxidation in the membrane structure and damage the cellular structure. The release of ROS could result in lipid peroxidation in the mitochondrial membrane. Cellular respiration and regeneration of ATP can be disrupted if there are damaged mitochondria, they are also a major cause of fatigue.

In this study, the administration of VCO during an exercise program can increase rats swimming time (Fig. 1). One of the supporting theories is that VCO can increase the durability of rats when doing maximum physical activity is because the content of VCO is rich in antioxidants and polyphenol compounds. The antioxidant content of VCO includes tocopherols, tocotrienols, flavonoids, and some polyphenol compounds [32]. The content of antioxidants and polyphenol compounds in VCO can reduce the occurrence of lipid peroxidation which is characterized by a decrease in MDA concentration (Fig. 3) and increase in the concentration of GPx levels (Fig. 2). Nevin in his study reported that VCO showed a significant antithrombotic effect in animal studies, where animals were fed with VCO, antioxidant vitamin levels also increased [33].

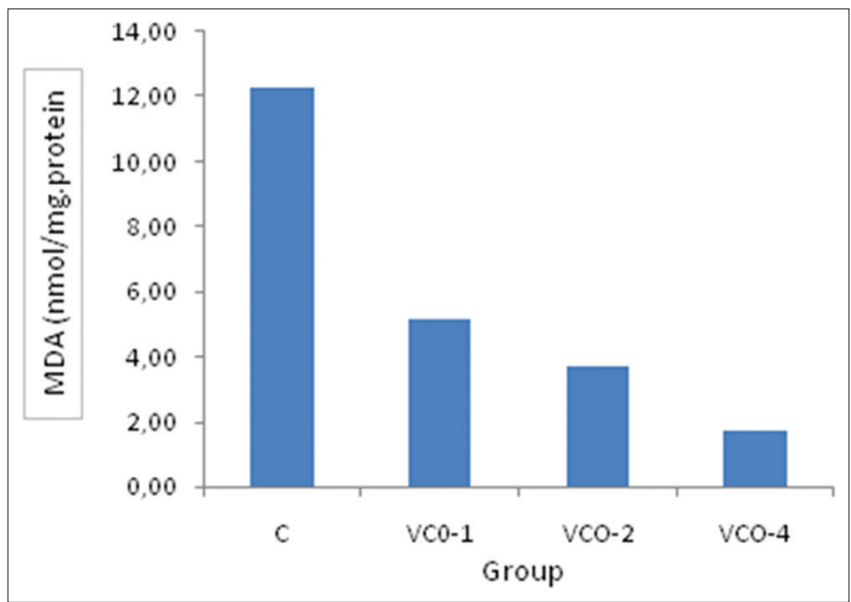

Fig. 3: Effect of virgin coconut oil on the malondialdehyde levels in the liver tissues of rats. Data are the mean $\pm S D$. ${ }^{*} p<0.05$ compared with the control (C) group

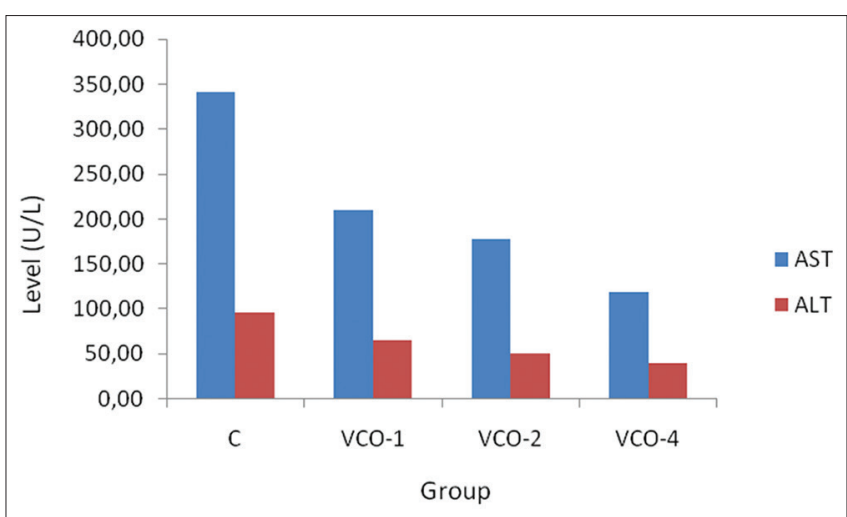

Fig. 4: Effect of virgin coconut oil on the aspartate transaminase and alanine transaminase levels in serum of rats. Data are the mean $\pm S D .{ }^{*} p<0.05$ compared with the control (C) group
Yeap et al. examined the antistress and antioxidant effects of VCO in vivo. In his study, the rats that were soaked in water caused lipid peroxidation which was characterized by an increase in MDA levels from 3.51 \pm 0.88 to $16.82 \pm 1.76 \mathrm{nmol} / \mathrm{g}$ protein and a decrease in superoxide dismutase (SOD) levels of $12.57 \pm 1.3$ to $5.97 \pm 1.77 \mathrm{U} / \mathrm{mg}$ protein. In the group of rats given $\mathrm{VCO}$ at a dose of $10 \mathrm{ml} / \mathrm{kgBW}$ reduced the lipid peroxidation process which was characterized by a decrease in MDA levels to $5.38 \pm 1.59 \mathrm{nmol} / \mathrm{g}$ protein accompanied by an increase in SOD levels of $9.85 \pm 1.26 \mathrm{U} / \mathrm{mg}$ protein.

This study shows a decrease in MDA levels, increased levels of endogenous antioxidants due to VCO administration were also reported by many researchers [28,34-37]. Dosumu et al. reported that VCO with a dose of $6.7 \mathrm{ml} / \mathrm{kg} \mathrm{BW}$ could reduce testicular MDA levels of rats induced with alcohol at a dose of $7 \mathrm{ml} / \mathrm{kg}$ BW with a significance level of $\mathrm{p}<0.001$. The study was conducted on five treatment groups, namely Groups I (control group), II (alcohol), III (alcohol-VCO), IV (alcohol/ $\mathrm{VCO})$, and $\mathrm{V}$ (VCO/alcohol), and MDA levels obtained for each group of $\mathrm{I}=10.68 \pm 1.04, \mathrm{II}=29.24 \pm 2.51, \mathrm{III}=8.45 \pm 1.07, \mathrm{IV}=6.62 \pm 0.70$, and $\mathrm{V}=18.01 \pm 2.45 \mathrm{nmol} / \mathrm{min}[38]$.

The antistress activity and antioxidants in VCO are associated with the presence of polyphenol compounds and medium chain fatty acids [39]. Antioxidant activities and phenolic compounds such as tocopherol and tocotrienol are found in VCO and are useful in the prevention of various chronic diseases including cancer and cardiovascular disease [40]. Determination of antioxidant status shows that defense against ROS increases with the administration of $\mathrm{VCO}$ and prevents lipid peroxidation [40].

Nevin and Rajamohan also reported the antioxidant effectiveness of VCO compared to copra (CO) oil and peanut oil (GO) with Vitamin E as a control. Vitamin E, 8\% VCO, 8\% COC, and 8\% GO were administered for 45 days in rats. The results showed that VCO increased the activity of enzyme catalase (CAT), SOD, glutathione reductase (GR), GPx, and decreased levels of MDA and conjugated dienes in liver, heart, and kidney organs compared to CO and GO [41]. Nandakumaran et al. also reported daily administration of VCO to rats for 30 days at a dose of $1 \mathrm{ml}$ (Group I), $2 \mathrm{ml}$ (Group II), and $4 \mathrm{ml}$ (Group III) can increase SOD levels. It is known that the enzymes SOD, CAT, GPx, and GR are endogenous antioxidants that function to neutralize free radicals formed in the body [42]. Increased levels of endogenous antioxidant activity (GSH, CAT, and SOD) and decreased MDA levels in diabetic-induced rats due to VCO administration have also been reported [43].

Besides containing antioxidants and polyphenol compounds, VCO also contains MCT. When viewed from the energy system in sports, the potential use of VCO which is rich in MCT is very potential to be used as a fast energy source available, especially for endurance sports. MCT is fast hydrolyzed, more complete than LCT, and absorbed faster. One of the unique natures of MCT is its solubility in water. This nature allows MCT to enter the blood circulatory system and then enter the liver through veins to be turned quickly into energy without being stored (buried) in the body tissues [44].

MCT is delivered in the form of free fatty acids into the blood faster than LCT. LCT is reesterified in the mucosa of the small intestine into chylomicron, which is a combination of LCT and albumin that enters the lymph channels and requires the enzyme carnitine to enter the mitochondria. MCT does not bind to albumin because MCT in the form of fatty acids is easier to interact with water (polar), rapidly absorbed into the portal vein directly into the liver and into the mitochondrial membrane to be oxidized to energy so that MCT is not accumulated in adipose tissue $[34,45]$. The nature of MCT that is not metabolized like conventional fat can be a good source of energy so it can increase endurance in rats that do the maximum physical activity. The results of this study are supported by Silalahi et al. who examined the effect of acute VCO administration on rats with a dose of $0.1 \mathrm{ml}, 0.2 \mathrm{ml}$, and $0.4 \mathrm{ml} / 20 \mathrm{~g}$ BW compared to palm oil. 
The results of his study concluded that the administration of VCO and palm oil in an acute manner could increase stamina, where the higher the concentration of fatty oil given the stronger the stamina produced. When compared to the effect of VCO with palm oil, VCO results are stronger to increase stamina compared to palm oil which is measured by the ability of swimming rats [35].

Exercise has various effects such as increasing nutritional metabolism and antioxidant capacity, also has an effect on skeletal muscle and liver function. Accumulating evidence indicates that exhaustive exercise could injure liver cells by decreasing blood flow in the liver [36] and the portal vein [35], which often causes hypoxia of hepatocytes, eventually inducing their necrosis. ALT and AST are a liver-specific enzyme. High levels of ALT and AST are indicative of liver injury $[37,38]$

As shown in Fig. 4, the AST and ALT levels of the liver of the VCO-1, VCO-2, and VCO-4 groups were significantly lower than the $\mathrm{C}$ group $(p<0.05)$. The decrease in AST and ALT levels in this study due to antioxidant activity and the content of polyphenol compounds found in VCO can reduce MDA levels (Fig. 3) and increase the antioxidant levels of GPx (Fig. 3). The results of this study are supported by research that reports the VCO dose of $10 \mathrm{ml} / \mathrm{kg}$ BW for 7 days can reduce liver damage induced by giving paracetamol dose of $3 \mathrm{~g} / \mathrm{kg} \mathrm{BW}$ in rats. Reduced liver damage is known from histopathological examination, decreased levels of AST, ALT, alkaline phosphate (ALP), and liver weight, and increased viability of rats liver cells $[24,46]$.

\section{CONCLUSION}

The results of the study show that giving VCO during exercise can increase the levels of endogenous antioxidant and reduce lipid peroxidation, ALT, and AST. These results indicate that VCO has an antioxidant and hepatoprotective effect on maximum physical activity.

\section{AUTHORS' CONTRIBUTIONS}

All the authors have the same contribution in this research (carried out the research, collected the data, analyzed the data, and formatted the manuscript).

\section{CONFLICTS OF INTEREST}

The authors declare that they have no conflicts of interest in this research and this article.

\section{REFERENCES}

1. Khan KM, Thompson AM, Blair SN, Sallis JF, Powell KE, Bull FC, et al. Sport and exercise as contributors to the health of nations. Lancet 2012:380:59-64.

2. Imayama I, Alfano CM, Mason CE, Wang C, Xiao L, Duggan C, et al. Exercise adherence, cardiopulmonary fitness and anthropometric changes improve exercise self-efficacy and health-related quality of life. J Phys Act Health 2013;10:676-89.

3. Powers SK, Ji LL, Kavazis AN, Jackson MJ. Reactive oxygen species: Impact on skeletal muscle. Compr Physiol 2011;1:941-69.

4. Lin Y, Liu HL, Fang J, Yu CH, Xiong YK, Yuan K, et al. Anti-fatigue and vasoprotective effects of quercetin-3-O-gentiobiose on oxidative stress and vascular endothelial dysfunction induced by endurance swimming in rats. Food Chem Toxicol 2014;68:290-6.

5. Echtay KS, Roussel D, St-Pierre J, Jekabsons MB, Cadenas S, Stuart JA, et al. Superoxide activates mitochondrial uncoupling proteins. Nature 2002;415:96-9.

6. Daniel RM, Stelian S, Dragomir C. The effect of acute physical exercise on the antioxidant status of the skeletal and cardiac muscle in the Wistar rat. Rom Biotechnol Lett 2010;15:56-61.

7. Wang L, Zhang HL, Lu R, Zhou YJ, Ma R, Lv JQ, et al. The decapeptide CMS001 enhances swimming endurance in mice. Peptides 2008;29:1176-82.

8. Lyle N, Gomes A, Sur T, Munshi S, Paul S, Chatterjee S, et al. The role of antioxidant properties of nardostachys jatamansi in alleviation of the symptoms of the chronic fatigue syndrome. Behav Brain Res 2009;202:285-90.

9. Sholikhah AM, Wirjatmadi B, Adriani M. Effects of purple sweet potatoes on oxidative stress biomarkers in rats subjected to exhaustive exercise. Health Notions 2018;2:174-7.

10. Yunarsa IP, Adiatmika IP. Levels of antioxidant superoxide dismutase (SOD) rat liver in heavy physical activity. J Med Udayana 2018;7:143-7.

11. Dröge W. Free radicals in the physiological control of cell function. Physiol Rev 2002;82:47-95.

12. Chevion S, Moran DS, Heled Y, Shani Y, Regev G, Abbou B, et al. Plasma antioxidant status and cell injury after severe physical exercise. Proc Natl Acad Sci U S A 2003;100:5119-23.

13. Pettersson J, Hindorf U, Persson P, Bengtsson T, Malmqvist U, Werkström V, et al. Muscular exercise can cause highly pathological liver function tests in healthy men. Br J Clin Pharmacol 2008;65:253-9.

14. Amah UK, Okoli SN, Ogbodo EC, Ezeugwunne IP, Analike RA, Onuegbu AJ, et al. Effect of short-term aerobic exercise on liver function of students college of health sciences and technology, nnamdiazikiwe university, nnewi campus, Anambra state, Nigeria. Glob Sci J 2017;5:67-77.

15. Sutarmi, Rozaline H. Taklukkan Penyakit Dengan VCO. Jakarta: Penebar Swadaya; 2006.

16. Vysakh A, Ratheesh M, Rajmohanan TP, Pramod C, Premlal S, Girish Kumar B, et al. Polyphenolics isolated from virgin coconut oil inhibits adjuvant induced arthritis in rats through antioxidant and antiinflammatory action. Int Immunopharmacol 2014;20:124-30.

17. Voon PT, Ng TK, Lee VK, Nesaretnam K. Virgin olive oil, palm olein, and coconut oil diets do not raise cell adhesion molecules and thrombogenicity indices in healthy Malaysian adults. Eur J Clin Nutr 2015;69:712-6.

18. Nevin KG, Rajamohan T. Beneficial effects of virgin coconut oil on lipid parameters and in vitro LDL oxidation. Clin Biochem 2004;37:830-5.

19. Babu AS, Veluswamy SK, Arena R, Guazzi M, Lavie CJ. Virgin coconut oil and its potential cardioprotective effects. Postgrad Med 2014;126:76-83

20. Shilling M, Matt L, Rubin E, Visitacion MP, Haller NA, Grey SF, et al. Antimicrobial effects of virgin coconut oil and its medium-chain fatty acids on Clostridium difficile. J Med Food 2013;16:1079-85.

21. Silalahi J, Permata YM, Putra ED. Antibacterial activity of hydrolyzed virgin coconut oil. Asian J Pharm Clin Res 2014;7:90-4

22. Elysa, Harahap U, Silalahi J. Antibacterial activity of enzymatic hydrolysis of virgin coconut oil against Salmonella. Int J PharmTech Res 2014;6:589-99.

23. Hayatullina Z, Muhammad N, Mohamed N, Soelaiman IN. Virgin coconut oil supplementation prevents bone loss in osteoporosis rat model. Evid Based Complement Alternat Med 2012;2012:237236.

24. Zakaria ZA, Rofiee MS, Somchit MN, Zuraini A, Sulaiman MR, Teh LK, et al. Hepatoprotective activity of dried- and fermentedprocessed virgin coconut oil. Evid Based Complement Alternat Med 2011;2011:142739.

25. Zakaria ZA, Somchit MN, Mat Jais AM, Teh LK, Salleh MZ, Long K, et al. In vivo antinociceptive and anti-inflammatory activities of dried and fermented processed virgin coconut oil. Med Princ Pract 2011;20:231-6

26. Cardoso DA, Moreira AS, de Oliveira GM, Raggio Luiz R, Rosa G. A coconut extra virgin oil-rich diet increases HDL cholesterol and decreases waist circumference and body mass in coronary artery disease patients. Nutr Hosp 2015;32:2144-52.

27. Hu Yang I, De la Rubia Ortí JE, Selvi Sabater P, Sancho Castillo S, Rochina MJ, Manresa Ramón N, et al. Coconut oil: Non-alternative drug treatment against Alzheimer's disease. Nutr Hosp 2015;32:2822-7.

28. Huang WC, Chiu WC, Chuang HL, Tang DW, Lee ZM, Wei L, et al. Effect of curcumin supplementation on physiological fatigue and physical performance in mice. Nutrients 2015;7:905-21.

29. Kan NW, Huang WC, Lin WT, Huang CY, Wen KC, Chiang HM, et al. Hepatoprotective effects of Ixora parviflora extract against exhaustive exercise-induced oxidative stress in mice. Molecules 2013;18:10721-32

30. Narkhede AN, Jagtap SD, Nirmal PS, Giramkar SA, Nagarkar BE, Kulkarni OP, et al. Anti-fatigue effect of samarkand on endurance exercise capacity in rats. Complement Altern Med 2016;16:1-7.

31. Roohi BN, Moradlou AN, Bolboli L. Influence of curcumin supplementation on exercise-induced oxidative stress. Asian J Sports Med 2017;8:e35776.

32. Srivastava Y, Semwal AD, Majumdar A, Yildiz F. Quantitative and qualitative analysis of bioactive components present in virgin coconut oil. Cogent Food Agric 2016;2:1164929.

33. Manikandan A, Meera R, Kannan E. Formulation and storage stability of beta carotene enriched Vitamin D3 and omega 3 fortified cold pressed virgin coconut oil. Int J Pharm Pharm Sci 2014;6:112-6. 
34. Man YC, Manaf MA. Medium-chain triacylglycerols. In: FereidoonS, editor. Nutraceutical and Specialty Lipids and Their Co-Products. New York: Taylor and Francis Group; 2006. p. 27-8, 33

35. Silalahi J, Pertiwi D, Dalimunthe A, Silalahi YC. Effect of acute consumption of coconut and palm oil on swimming capacity endurance of mice (Mus musculus). Int J PharmTech Res 2015;8:55-9.

36. Rowell LB, Blackmon JR, Bruce RA. Indocyanine green clearance and estimated hepatic blood flow during mild to maximal exercise in upright man. J Clin Invest 1964;43:1677-90.

37. Duan FF, Guo Y, Li JW, Yuan K. Antifatigue effect of luteolin-6$\mathrm{C}$-neohesperidoside on oxidative stress injury induced by forced swimming of rats through modulation of nrf2/ARE signaling pathways. Oxid Med Cell Longev 2017;2017:3159358.

38. Dosumu OO, Duru FI, Osinubi AA, Oremosu AA, Noronha CC. Influence of virgin coconut oil (VCNO) on oxidative stress, serum testosterone and gonadotropic hormones (FSH, LH) in chronic ethanol ingestion. Agric Biol J N Am 2010;1:1126-32.

39. Yeap SK, Beh BK, Ali NM, Yusof HM, Ho WY, Koh SP, et al. Antistress and antioxidant effects of virgin coconut oil in vivo. Exp Ther Med 2015;9:39-42.

40. Nur'azimatul QH, Norhayati A. Protective and antidiabetic effects of virgin coconut oil (VCO) on blood glucose concentration in alloxan induced diabetics rats. Int J Pharm Pharm Sci 2015;7:57-60.

41. Nevin KG, Rajamohan T. Virgin coconut oil supplemented diet increased the antioxidant status in rats. Food Chem 2006;99:260-6.

42. Nandakumaran M, Al-Sarraf H, Al-Fadhli R, Al-Shammari M, AlHarmi J, Al-Saleh E. Effect of oral administration of coconut oil on hematological and metabolic parameters in female adult rats. Nutr Ther Metab 2009;27:183-8.

43. Iranloye B, Oludare G, Olubiyi M. Anti-diabetic and antioxidant effects of virgin coconut oil in alloxan-induced diabetic male sprague dawley rats. J Diabetes Mellit 2013;3:221-6.

44. Bach AC, Babayan VK. Medium-chain triglycerides: An update. Am J Clin Nutr 1982;36:950-62.

45. Fushiki T, Matsumoto K, Inoue K, Kawada T, Sugimoto E. Swimming endurance capacity of mice is increased by chronic consumption of medium chain triglycerides. J Jpn Inst Nutr 1994;22:531-9.

46. Rofiee MS, Zakaria ZA, Somchit MN, Zuraini A, Arifah AK, Teh LK, et al. Involvement of CYP450 system in hepatoprotective activity of Malaysian agricultural research and development institute (MARDI) produced virgin coconut oils. Afr J Pharm Pharmacol 2011;5:2526-36. 